九州歯会誌 45 (4): $555 \sim 557,1991$.

臨床における咬合誘導法の将来性

一技術的問題点と工夫点一

浜 野 良彦

小児歯科はまの 福岡市

\title{
A Clinical Prospect of Occlusal Guidance
}

Yoshiko Hamano

Hamano Pedodontic Office, Fokuoka, Japan

\section{はじめに}

厚生省の歯料疾患実態調査の結果からわかるように, 乳歯䀞触の罹患状況にこの数年来変化がみられ減少傾向 にあることが示されている．日々の臨床において感じら

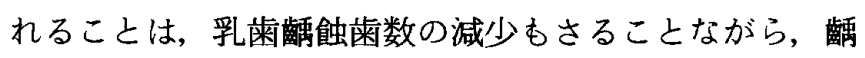
蝕の進行程度にも顕著な違いがみられ, 重度粫蝕（ラン パントカリエス）を有する患児を治療する機会が減少し ているようである，われわれ臨床に携わる者によって， 乳歯䶖蝕が汇濫していたころからの長い間の苦労が徐々 にではあるが，ようやく報いられつつあるようだ。この ように, 䠘蝕の減少が進めば進むほど, 日々の治療で目 につくのが不正咬合である，その原因論はさて扔き患者

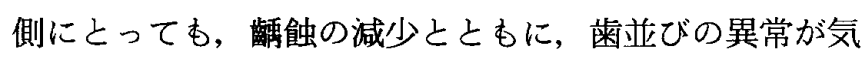
になるようである.

\section{咬合誘導における主訴}

1 才 6 力月あるいは 3 才児健診において, 乳歯齲蝕だ けでなく乳歯列の咬合異常を指摘され, 保護者が積極的 に歯科を受診する場合が増えてきているように思える。 このように歯科医師側にとってす小児の歯列異常に目を 向けるだけの口腔環境が備ってきたと同時に保護者に

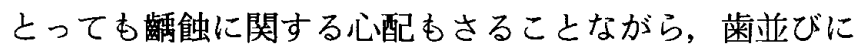
ついての心配す増加する社会状況にあるようである。

ちなみに，乳歯列期とくに 3 才末満児に执いては，反 対咬合に関する相談が最も多く, 次に吸指癖による開咬 に関する相談が多い，ほとんどの場合健診時の歯科医師 の指摘および指導によるものである，混合苗列前期にお いては, 叢生に関する相談が圧倒的に多く, 私の医院で は，この場合本格的矯正治療を行うこととなる. 当然な がら主訴が患児本人の場合は少なく, 保護者が我が子の
蒾並びが気になることに端を発しているようである。ま た，小学校も高学年ともなると患児本人からの主訴によ り来院する場合が増し，混合歯列後期あるいは，すでに 永久歯列が完成しており，明らかに矯正治療を目的とし て来院するのである. 患者の主訴が何に, あるいは誰に よって起因しているのかを知ることは，治療の成否にか かわる重要なことであり，咬合誘導処置と矯正処置との 違いはこの出発点から明確にみられるのである.

\section{能動的咬合誘導と受動的咬合誘導}

咬合誘導の語源を諮ってみると, 小児歯科学雑誌 1 巻 1 号にその最初を見い出すことができる. 全文は紙面の 都合上省略するが, 今日では, 咬合誘導についての定義 は広義と狭義に分けられ，狭義の咬合誘導は受動的およ び能動的咬合誘導の 2 つに大別されている.

すなわち，現状を維持することによって不正咬合の発 生を防止しょうとする受動的咬合誘導と, 形態あるいは 機能の異常を早期に発見し, 積整的に正常な発育へと導 く能動的咬合誘導に分けられる。このように一般的にい われている保隙処置は受動的咬合誘導処置なのである. 近年, 咬合誘導というと, 歯列上に何らかの異常か認め られた場合の対処の仕方について語られる場合がほとん どであり，正しくは能動的咬合誘導と呼称すべきすのを 能動的という言葉を省略して，従来から用いられている 咬合誘導という言葉だけが 1 人歩きしているように思わ れてならない。

受動的咬合誘導 図1に示すように，正常な永久雪 列を獲得する諸条件として，いろんな要因が考えられる が，基本的には，正常な柬の交換現象を導くことによ り，正常咬合が成立するといわれている．受動的咬合誘 導姏置では, 今ある現在の乳歯列をそのままの姿で維持 


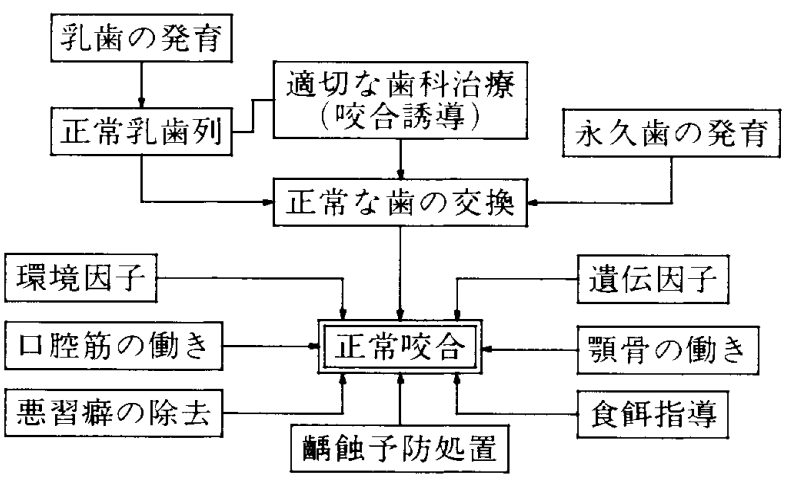

図 1 正常咬合の成り立ち

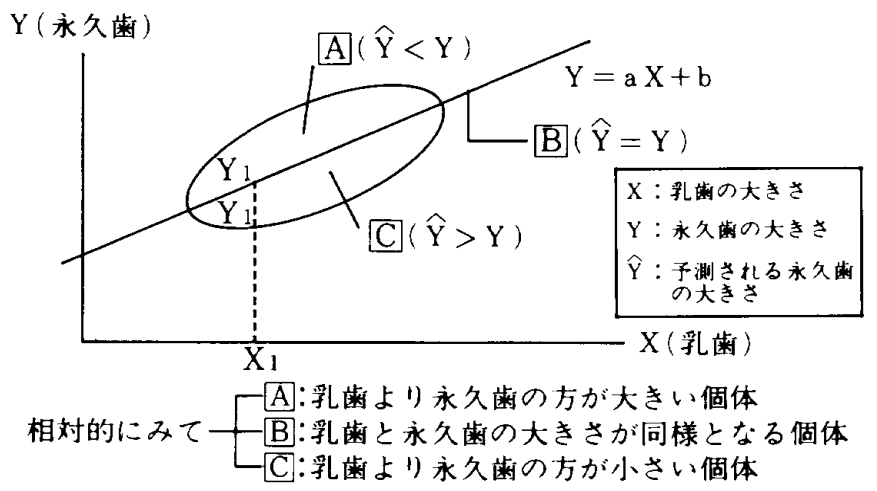

図 2 乳歯と永久歯の大きさの相関図（浜野ら）

することを目的としており，その主たる処置内容が保隙 処置ということになる，では，保隙処置だけで正常な永 久歯列の完成が成し得るのかというと, 図 2 に示すよう な乳歯之永久歯の近遠心幅径の大きさの相関図で数学的 に説明がつく，すなわち乳歯の大きさよりあ相対的に大 きい永久歯が萌出してくる場合, すなわち叢生が発現す る個体が図 2 中の $\mathrm{A}$ で示される部分に相当し，それ以 外すなわち健全な永久歯列が成立する個体が $\mathrm{B}$ 打よび Cに相当する. 健全な永久歯列を期待しうる頻度は表 1 に示すように相関係数から算出される $63 \%$ となる．ま た, 臨床的調查結果として表 1 のごとく正常乳歯列で あったものが永久歯列に交換した場合叢生を生じる割合 が報告されている（表 2)。そこで理解しておかなけれ ばならないことは，保腙の有効性を患児の保護者に説明 した上で保腙処置を行ったとしても叢生が生じる症例が $1 / 3$ の割合で発現することである.

能動的咬合誘導 歯科矯正学の教科書には, 臨床矯 正学は予防的矯正 Preventive Orthodontics, 抑制的 矯正 Interceptive Orthodontics 抢上び矯正治療 Corrective Orthodontics の 3 つの大きな柱からなること
表 1 相関係数から求められる期待率（浜野ら）

\begin{tabular}{ccc}
\hline \hline 相関係数 & 決定係数 $(\%)$ & $\begin{array}{c}\text { 健全な永久歯列を } \\
\text { 期待しうる頻度 }(\%)\end{array}$ \\
$\gamma$ & $\gamma^{2} \times 100$ & $\left(\gamma^{2}+\frac{1-\gamma^{2}}{2}\right) \times 100$ \\
\hline 0.1 & 1 & 51 \\
0.2 & 4 & 52 \\
0.3 & 9 & 55 \\
0.4 & 16 & 58 \\
0.5 & 25 & 63 \\
\hline 0.6 & 36 & 68 \\
0.7 & 49 & 75 \\
0.8 & 64 & 82 \\
0.9 & 81 & 91 \\
1.0 & 100 & 100 \\
\hline
\end{tabular}

表 2 健全乳歯列（77例）加ら永久歯不正 咬合の発現率之種類

\begin{tabular}{c|r|r}
\hline \hline 正常咬合 & \multicolumn{2}{|c}{37 例 $(48.1 \%)$} \\
\hline & 反対咬合 & 2例 $(2.6 \%)$ \\
不正咬合 & 上靧前 突 & 2例 $(2.6 \%)$ \\
40 例 & 過蓋 咬 & 8例 $(10.4 \%)$ \\
$(51.9 \%)$ & 空隙歯列 & 9例 $(11.7 \%)$ \\
& 叢生歯列 & 19 例 $(24.6 \%)$ \\
\hline
\end{tabular}

（東歯大）

が明記されている。こころが現在では矯正治療 Corrective Orthodontics の分野が臨床の大部分を占め ており，予防および抑制的矯正に関する記述を目にする 機会が少ないように思われる.ところで小児苗科での能 動的咬合誘導の基本的概念之矯正歯科での予防掞よび抑 制的矯正のそれを比へてみると，互に一致する点が多い のである．ところが日常臨床において出現する種々なる 問題に対して，どのような技術を用いるかは，小児歯科 医であれ，矯正歯科医であれ術者の技術の修得程度によ りおおいに差がみられる．常に考えておかね枋ならない ことは，能動的咬合誘導処置だからといって決して安易 に考えずに，自分の能力にあった症例を選び治療を行う ことである，そのためには，正確な診断と綿密な治療計 画が必要になってくる.

\section{機能的額稪正法と筋機能訓練法}

近年，矯正学の臨床分野において，改めて注目を集め ているのが機能的顎矯正法で，いわゆる F.K.O. と呼ば 
れるものである．成長期にある小児の口腔全域の管理を 担当する小児歯科医として，この機能的顎矯正法の基本 的理論及び技術を修得しておくと，大変便利である，と いうょり著者は，これからの咬合誘導臨床の 1 手段とし て重要な位置を占めるべきではないかと考えている.

Andresen が考案したこの方法は現在ではヨーロッパ の矯正学の長い歴史の中で, 中心的技術として常に $\mathrm{E}$. J.O. (Europian Journal of Orthodontics) の紙面を にぎわしている．これまで数多くの装置が考案され，そ して紹介されているが，私の知る限りでは，Frönkel の 装置は例外之して，ほとんどの装置が Andresen の理 論を基礎として, 現在に発展していると考えられる.す なわち Andresen の理論を理解しさえすれば，多少複 雑な機能的顎矯正装置であっても十分使いこなせるし， 失敗の危険性む少ないようである.

日本に打汀る約 30 年間の小児歯科臨床を振返ってみ ると，この機能的靧矯正法の技術的紹介を含め多数の論 文があるが，咬合誘導処置の 1 手段としては，体系づけ られるには至ってない，そこで，著者はこのF.K.O.の 技術導入により矯正治療に対して咬合誘導処置の差別化 が可能ではないかと考えている．また，M.F.T.（筋機 能訓練法）の技術む大いに注目に值するむのと考えてい る. 咀夁機能を正しく発育させるためには，これからの 食生活の変化に対応していかねばならないことを考える と, M. F. T. の理論を臨床に応用していく必要にせまら れる時が近い将来訪れると考えている．このように小児 歯科に扮ける能動的咬合誘導の技術的な将来性を考える と，F.K.O.と M.F.T.の技術を積極的に取入れ，近い 将来能動的咬合誘導処置の中で体系ずけられるべきであ ると考えている.

\section{まとめ}

歯科一般を主に行なわれている先生方によく相談を受 けることがある．矯正は，(技術的に）難しいけれど, 咬合誘導だったら自分であ何とかやれるのではないかと 考え，咬合誘導処置法について教えてほしいとの相談内 容がほとんどである．多くの先生方が，前述の受動的咬 合誘導之能動的咬合誘導の内容を十分に理解されないま まに咬合誘導という語彙から受ける刋象から少々の外的
作用（簡単な矯正的処置）により, 簡単に正常咬合へ導 けると理解されがちである。すすなわち咬合誘導処置で は，矯正治療のような難易度の高い技術は使わずに，技 術的に簡単な方法で治療できると考えられているように 思えてならない。

そこで，考えておかねばならない重要な問題がある. 前にむ述べたが矯正処置における患者の主訴は，すでに 異常が明確に現れているものに対しての処置を希望する あのであるが，小児歯科で行う能動的咬合誘導法は，患 者側からの主体的な主訴というょりも，術者即ち歯科医 師が異常之認め，患者側に治療をうながす場合が多く， 矯正治療之異なった出発点が存在するのである. 即ち可 及的早期に異常をみつけ, あるいは異常が起り得る兆候 を前もって察知し，患者に指導するのむ私ざす小坚歯科 医の努めであるため，このような問題が起ってくるので ある．保護者が，今まで気にも留めなかった口腔内の変 異（異常とまではいかない程度の違いについてお）に気 を留めざるを得なくなる場合が生じてくるのである。で は患者側の主訴が芽生えるまで治療の開始時期を待った とすると，時として治療開始時期が遅くれてしまい，あ らゅる点において複雑な矯正治療の段階にはいってしま うことになる．それでは今まで定期的に口腔内診査を行 い，1 ロ腔単位として健康管理を行っていた側として責 務を果せたかというと大いに疑問点を残す結果となって しまうのである．すなわち正常咬合を有する永久歯列に なるように䠛蝕治療を行いあるいは保隙処置を行ってき た努力が水泡に帰するだけでなく, 患者側の信頼をも失 う結果にならないとは限らないのである.

私の結論として能動的晈合誘導処置の最終目的は矯正 処置のそれと同じであり正常な永久歯列の完成というこ とになる．また咬合誘導処置だからといって用いる技術 が矯正処置のそれよりあ劣ってよいわけではない，なぜ ならば患者は, 咬合誘導処置と矯正処置とに違いを認め ていないからである.

今回，咬合誘導に対する私見を述べる機会をお与えい ただきました同空会の諸先生方に紙上をお借りして心か ら感謝いたします。 